\title{
HIV-1 viral load and resistance in genital secretions in patients taking protease-inhibitor-based second-line therapy in Africa
}

Anne Hoppe, Marina Giuliano, Abbas Lugemwa, Jennifer A Thompson, Marco Floridia, Ann S Walker, Ismail Senoga, Mary C Abwola, Maria F Pirillo, Cissy M Kityo, Alejandro Arenas-Pinto, Nicholas I Paton, the EARNEST Trial Team

Antiviral Therapy 2017; 10.3851/IMP3200

Submission date 30th June 2017

Acceptance date 1st October 2017

Publication date 12th October 2017

This provisional PDF matches the article and figures as they appeared upon acceptance.

Copyedited and fully formatted PDF and full text (HTML) versions will be made available soon.

For information about publishing your article in Antiviral Therapy go to http://www.intmedpress.com/index.cfm?pid=12 


\section{Short communication}

\section{HIV-1 viral load and resistance in genital secretions in patients taking protease- inhibitor-based second-line therapy in Africa}

Anne Hoppe ${ }^{1,2 *}$, Marina Giuliano ${ }^{3}$, Abbas Lugemwa4 $^{4}$, Jennifer A Thompson², Marco Floridia $^{3}$, Ann S Walker ${ }^{2}$, Ismail Senoga ${ }^{5}$, Mary C Abwola ${ }^{6}$, Maria F Pirillo ${ }^{3}$, Cissy M $K_{\text {Kityo }}{ }^{7}$, Alejandro Arenas-Pinto ${ }^{2}$, Nicholas I Paton ${ }^{2,8}$, the EARNEST Trial Team ${ }^{\dagger}$

${ }^{1}$ Infection and Immunity, University College London, London, United Kingdom

${ }^{2}$ MRC Clinical Trials Unit at University College London, London, United Kingdom

${ }^{3}$ Istituto Superiore di Sanità, Rome, Italy

4Joint Clinical Research Centre (JCRC), Mbarara, Uganda

${ }^{5} \mathrm{St}$ Francis of Nsambya Hospital, Kampala, Uganda

${ }^{6} J C R C$, Mbale, Uganda

7JCRC, Kampala, Uganda

${ }^{8}$ Yong Loo Lin School of Medicine, National University of Singapore, Singapore

*Corresponding author e-mail: a.hoppe@ucl.ac.uk

†Members of the EARNEST Trial Team are listed in the Supplementary Materials

\section{ABSTRACT}

Background: HIV is transmitted primarily through sexual intercourse, and the objective of this study was therefore to assess whether there is occult viral replication and resistance in genital secretions in patients on protease inhibitor (PI)-based second-line therapy.

Methods: HIV-infected adults taking ritonavir-boosted lopinavir with either two NRTIs, raltegravir, or as monotherapy for 96 weeks were enrolled at seven clinical sites in Uganda. Viral load (VL) was measured in cervico-vaginal secretions or semen and in a corresponding plasma sample. Genotypic resistance was assessed in genital secretion samples and plasma samples. Results were compared between compartments and with the plasma resistance profile at first-line failure.

Results: Of the 111 participants enrolled (91 female, 20 male), 16 (14\%) and 30 $(27 \%)$ had $V L>1000$ and $>40$ copies $/ \mathrm{ml}$ respectively in plasma; $3(3 \%)$ and 23 $(21 \%)$ had VL $>1000$ copies $/ \mathrm{ml}$ and $>40$ copies $/ \mathrm{ml}$ respectively in genital secretions. There was $74 \%$ agreement between plasma and genital secretion VL classification above/below 40 copies/ml threshold (kappa-statistic $=0.29$; $\mathrm{p}=0.001$ ). RT mutations (both $\mathrm{NRTI}$ and NNRTI) were detected in genital secretions in 4 patients (similar profile to corresponding plasma sample at first-line failure) and PI mutations were detected in 2 (1 polymorphism with no impact on resistance; 1 with high-level PI resistance).

Conclusions: High level (>1000 copies/ml) viral replication and development of new RT or PI resistance in the genital compartment were rare. The risks of 


\section{transmission arising from resistance evolution in the genital compartment are likely to be low on PI-based second-line therapy.}

Accepted 1 October 2017, published online 12 October 2017

Running head: HIV-1 viral load and resistance in genital secretions

\section{INTRODUCTION}

HIV is transmitted primarily through vaginal and anal intercourse, and a high concentration of HIV in semen and cervico-vaginal fluid has been shown to be an independent risk factor for HIV transmission after adjustment for plasma VL [1]. The genital tract and blood are separate immunologic compartments and HIV may replicate and evolve differently in the two resulting in different levels of infectivity of blood and genital secretions, and in a different spectrum of drug resistance-associated mutations [2-5]. Therefore, it is important that antiretroviral therapy suppresses HIV replication in both blood and genital secretions.

Antiretroviral drugs differ in genital compartment penetration. Nucleoside-reversetranscriptase-inhibitors (NRTIs) are concentrated in genital secretions, and non-NRTIs (NNRTIs) and raltegravir both reach similar concentrations in genital secretions and plasma [6-9]. However, ritonavir-boosted protease inhibitors (bPIs) do not penetrate well into cervico-vaginal fluid $[6,7,10]$ or semen [11,12].

This study aimed to estimate the prevalence of viral replication and the prevalence and profile of resistance mutations in genital secretions compared to plasma in patients taking PI-based secondline therapy in a large clinical trial of several regimen options administered using the public health approach.

\section{METHODS}

This was a sub-study of EARNEST, an open-label, randomised second-line therapy trial conducted in sub-Saharan Africa. In this trial, patients failing first-line NRTI/NNRTI treatment by WHO criteria were randomised to one of three different treatment regimens containing ritonavir-boosted lopinavir with either two NRTIs (PI/NRTI), raltegravir (PI/RAL), or alone as monotherapy after a 12-week induction period with raltegravir (PI-mono) [13].

Adult Ugandan EARNEST participants were offered participation in this sub-study, at a singlevisit 96 weeks after starting second-line therapy. Cervico-vaginal secretions were collected by selfswab or routine cervical smear (swab kit: eNAT, Copan Italia, Brescia, Italy). Male participants provided a fresh semen sample. Plasma was collected at week 96 in the EARNEST trial for retrospective viral load (VL) testing and genotyping.

VL in genital secretions was measured at the Istituto Superiore di Sanità (ISS), Rome, Italy using the Versant kPCR 1.0 assay (Siemens Healthcare Diagnostics, Deerfield, IL, USA). Samples 
with detectable VL ( $\geq 40$ copies $/ \mathrm{ml}$ ) were tested for the presence of drug resistance using the TruGene Genotyping kit (Siemens Healthcare Diagnostics).

VL in plasma was measured at the Joint Clinical Research Centre (JCRC), Kampala, Uganda using the Abbott RealTime HIV-1 assay. Genotypic resistance testing of week 96 plasma samples (with VL $>400$ copies/ml) was performed at Janssen Diagnostics, Michelen, Belgium. Genotypic testing (reverse transcriptase (RT) only) was performed on baseline samples (PI/NRTI and PI/RAL arms only) at the JCRC using in-house primers. Drug-susceptibility predictions were made using the Stanford algorithm $\mathrm{v} 7$.

The association between viral suppression in genital secretions and second-line treatment regimen, sex, age, plasma VL and CD4 cell count at second-line therapy initiation (baseline), and CD4 cell count at week 96 was assessed using Fisher's exact test for binary and exact-logistic regression for continuous variables. The Kappa-statistic was used to assess concordance between suppression in plasma and genital secretions at week 96 . The sub-study was approved by the Ugandan Ethics Committee and all participants provided written informed consent.

\section{RESULTS}

We enrolled 111 participants (91 female; 20 male; median age 36 years) at 7 Ugandan sites (34 on $\mathrm{PI} / \mathrm{NRTI}, 49$ on PI/RAL and 28 on PI-mono; the $\mathrm{PI}$ was ritonavir-boosted lopinavir in all cases). Of these, $16 / 111(14 \%)$ and 30/111 (27\%) had plasma VL>1000 copies/ml and $>40$ copies $/ \mathrm{ml}$ respectively at week 96 .

VL in the genital secretions was $>1000$ copies $/ \mathrm{ml}$ and $>40$ copies $/ \mathrm{ml}$ in 3/111 $(3 \%$; 2 in $\mathrm{PI} / \mathrm{NRTI}, 1$ in PI/RAL) and 23/111 (21\%) respectively. There was no difference in proportion of patients $>40$ copies/ml between the regimens $7 / 34(21 \%)$ in PI/NRTI, 10/49 (20\%) in PI/RAL, 6/28 $(21 \%)$ in $\mathrm{PI}-\mathrm{mono} ; \mathrm{P}=1.00)$ and no difference by gender, age, plasma VL or CD4 cell count at start of second-line therapy, or CD4 cell count at week 96 (all $\mathrm{P}>0.24$ ).

There was $74 \%$ agreement between the plasma and genital secretions classification of VL above/below 40 copy threshold at week 96.11 (10\%) participants had a $\mathrm{VL}<40$ copies/ml in plasma and a VL $>40$ copies $/ \mathrm{ml}$ in genital secretions, whereas 18 (16\%) participants had a $\mathrm{VL}>40$ copies $/ \mathrm{ml}$ in plasma and a $\mathrm{VL}<40$ copies $/ \mathrm{ml}$ in genital secretions (kappa-statistic $=0.29 ; \mathrm{p}=0.001$; Figure 1 ). $\mathrm{VL}$ values in genital secretions were low (maximum $1330 \mathrm{copies} / \mathrm{ml}$ ) but varied more widely in plasma (maximum $>1,000,000$ copies $/ \mathrm{ml}$ ).

Sequences were obtained for $6 / 23(26 \%)$ participants (all female) with VL>40 copies $/ \mathrm{ml}$ in genital secretions; five had resistance mutations (Table 1). Four participants had NRTI and NNRTI mutations, mostly similar to their plasma sample at first-line failure, apart from A98G seen in 3 genital secretions samples. Two patients had PI mutations one (taking PI/NRTI) with a K20R polymorphism with no impact on PI susceptibility; the other (taking PI-mono) with M46L, 154V and V82A mutations conferring high-level resistance to LPV/r but retaining susceptibility to DRV/r. These mutations were not present in the plasma sample at first-line failure. Of the 5 participants with resistance mutations in 
Publication: Antiviral Therapy; Type: Short communication

DOI: $10.3851 / \mathrm{IMP} 3200$

genital secretions at week 96, only one had a corresponding plasma sequence from week 96 (no resistance mutations seen); the others had $\mathrm{VL}<400$ copies/ml in plasma and were not tested.

\section{DISCUSSION}

This is the first study to our knowledge to measure VL in genital secretions in patients in sub-Saharan Africa taking a second-line PI-based regimen. Patients were managed with predominantly nurse-led care and without real-time VL monitoring, typical of the majority of settings in in which ART is delivered in sub-Saharan Africa. The proportion with detectable VL in plasma was comparable to that seen in the main EARNEST trial and other second-line trials [14,15] (and compatible with UNAIDS targets).

ART coverage is being currently expanded in order to reduce community transmission of HIV and ultimately end the HIV epidemic. The underlying assumption that complete suppression of viral replication in plasma will result in decreased transmission is less certain for patients on PI-based second-line therapy given the known poor penetration of Pls into the genital compartment $[7,11,12,16]$, and given the potential for cross-resistance of NRTIs to the NRTIs and NNRTIs provided as part of first-line therapy in settings where failure is often detected late and where resistance testing is not performed at the time of treatment failure.

Our finding that only 3 patients (3\%) had VL>1000 copies/ml in the genital secretions after 96 weeks of treatment, is therefore reassuring. A larger proportion had detectable $\mathrm{VL}>40 \mathrm{copies} / \mathrm{ml}$, but at low levels that are unlikely to represent a substantial risk of transmission [1]. Our finding that some patients with undetectable virus in plasma had detectable virus in genital secretions is consistent with an earlier study of second-line therapy in Thailand that found one third participants had a similar mismatch [17] and with the known imperfect correlation between VL in plasma and genital secretions in untreated patients $[1,18]$. Our low rates of viral detection in genital secretions are consistent with the $11 \%$ viral detection (40 copies/ml threshold) in semen of African men (11\%) on first-line therapy [19].

As a consequence of the low level of virus present, few sequences could be generated from genital secretions. Nevertheless our data make an important contribution to the existing sparse data on resistance in this compartment in patients receiving ART in programmes following the public health approach in sub-Saharan Africa and allow several inferences. Firstly, the similarity of the resistance pattern in the 4 patients with RT mutations detected at week 96 and the pattern in their baseline plasma sample (taken after a substantial period of first-line failure), including both NNRTI and NRTI resistance mutations, suggests that the genital secretions resistance mutations are the result of persistence of resistant virus or re-emergence of archived resistance, rather than ongoing resistance evolution in this compartment. The only consistent mutation present at week 96 but not in baseline plasma (A98G, present in 3 participants), is an NNRTI mutation that is also likely to have been archived rather than evolving on second-line regimens (none contained NNRTIs). Persistent NNRTI mutations in semen after full reversion in blood were reported in a previous small study [20]. As with 
Publication: Antiviral Therapy; Type: Short communication

DOI: $10.3851 / \mathrm{IMP} 3200$

accumulation of such resistance mutations on first-line therapy [21], the persistence of NRTI and NNRTI mutations in the genital tract on second-line therapy is of some concern in view of the potential transmission risk in any patients who later fail on second-line therapy with higher genital secretion viral loads.

Secondly, we found minimal resistance to the PI with only one patient $(<1 \%)$ having resistance in the genital tract, accompanied by a moderate VL (907 copies/ml) in this compartment. This patient was on a PI monotherapy regimen which, as a result of the findings of the EARNEST trial and others, is no longer considered an appropriate treatment option for the public health approach to ART. Thus, in spite of poor penetration, overall there appears to be a low risk of transmission of PI resistance on second-line therapy in these settings.

In summary, this sub-study bolsters our confidence in the WHO recommendation of PI-based second-line therapy for the public health approach, confirming that occult viral replication and resistance evolution in the genital tract are unlikely to represent a threat to long-term treatment outcomes and the desired goal of control of community HIV transmission.

\section{ACKNOWLEDGEMENTS}

We thank Clementina Maria Galluzzo (ISS) for performing the resistance analysis on genital secretions and all the patients and staff participating in this study at San Raphael of St. Francis Hospital, the Joint Clinical Research Centre (JCRC) in Kampala, and JCRC's Regional Centres of Excellence in Fort Portal, Kabale, Kakira, Mbale and Mbarara.

The study was funded the Istituto Superiore di Sanità (ISS), Italy. The main EARNEST trial was funded by the European and Developing Countries Clinical Trials Partnership (EDCTP, Grant Code: IP.2007.33011.003) with contributions from the Medical Research Council, UK; Institito de Salud Carlos III, Spain (Grant A107/90015); Irish Aid, Ireland; Swedish International Development Cooperation Agency (SIDA), Sweden; Instituto Superiore di Sanita (ISS), Italy and Merck, USA. Substantive in-kind contributions were made by the Medical Research Council Clinical Trials Unit, UK, CINECA, Bologna, Italy, Janssen Diagnostics, Beerse, Belgium; Abbott Laboratories, USA. Trial medication was donated by AbbVie, Merck, Pfizer, GSK and Gilead. Additional funding for resistance testing and VL testing was provided by the World Health Organisation and GSK.

\section{Disclosure Statement}

The institution of ASW has received funding from Janssen and Gilead Sciences. AAP has received research grants, or in kind support for research projects, or been investigator and co-investigator in clinical trials sponsored by Abbott/AbbVie, Boehringer Ingelheim, Bristol-Myers Squibb, Gilead Sciences, Janssen Cilag, Pfizer and ViiV Healthcare. For the remaining authors no conflicts of interest were declared.

\section{REFERENCES}

1. Baeten JM, Kahle E, Lingappa JR, et al. Genital HIV-1 RNA predicts risk of heterosexual HIV1 transmission. Sci Transl Med 2011; 3:77ra29.

2. Eron JJ, Vernazza PL, Johnston DM, et al. Resistance of HIV-1 to antiretroviral agents in blood and seminal plasma: implications for transmission. AIDS 1998; 12:F181-F189.

3. De Pasquale MP, Leigh Brown AJ, Uvin SC, et al. Differences in HIV-1 pol sequences from female genital tract and blood during antiretroviral therapy. J Acquir Immune Defic Syndr 2003; 34:37-44.

4. Ghosn J, Viard JP, Katlama C, et al. Evidence of genotypic resistance diversity of archived and circulating viral strains in blood and semen of pre-treated HIV-infected men. AIDS 2004; 18:447457. 
5. Tirado G, Jove G, Kumar R, et al. Differential virus evolution in blood and genital tract of HIVinfected females: evidence for the involvement of drug and non-drug resistance-associated mutations. Virology 2004; 324:577-586.

6. Dumond JB, Yeh RF, Patterson KB, et al. Antiretroviral drug exposure in the female genital tract: implications for oral pre- and post-exposure prophylaxis. AIDS 2007; 21:1899-1907.

7. Kwara A, Delong A, Rezk N, et al. Antiretroviral drug concentrations and HIV RNA in the genital tract of HIV-infected women receiving long-term highly active antiretroviral therapy. Clin Infect Dis 2008; 46:719-725.

8. Barau C, Delaugerre C, Braun J, et al. High concentration of raltegravir in semen of HIVinfected men: results from a substudy of the EASIER-ANRS 138 trial. Antimicrob Agents Chemother 2010; 54:937-939.

9. Clavel C, Peytavin G, Tubiana R, et al. Raltegravir concentrations in the genital tract of HIV-1infected women treated with a raltegravir-containing regimen (DIVA 01 study). Antimicrob Agents Chemother 2011; 55:3018-3021.

10. Min SS, Corbett AH, Rezk N, et al. Protease inhibitor and nonnucleoside reverse transcriptase inhibitor concentrations in the genital tract of HIV-1-infected women. $J$ Acquir Immune Defic Syndr 2004; 37:1577-1580.

11. Taylor S, Back DJ, Drake SM, et al. Antiretroviral drug concentrations in semen of HIVinfected men: differential penetration of indinavir, ritonavir and saquinavir. J Antimicrob Chemother $2001 ; 48: 351-354$.

12. Sankatsing SU, Droste J, Burger D, et al. Limited penetration of lopinavir into seminal plasma of HIV-1-infected men. AIDS 2002; 16:1698-1700.

13. Paton NI, Kityo C, Hoppe A, et al. Assessment of second-line antiretroviral regimens for HIV therapy in Africa. N Engl J Med 2014; 371:234-247.

14. Boyd MA, Kumarasamy N, Moore CL, et al. Ritonavir-boosted lopinavir plus nucleoside or nucleotide reverse transcriptase inhibitors versus ritonavir-boosted lopinavir plus raltegravir for treatment of HIV-1 infection in adults with virological failure of a standard first-line ART regimen (SECOND-LINE): a randomised, open-label, non-inferiority study. Lancet 2013; 381:2091-2099.

15. La Rosa AM, Harrison LJ, Taiwo B, et al. Raltegravir in second-line antiretroviral therapy in resource-limited settings (SELECT): a randomised, phase 3, non-inferiority study. Lancet HIV 2016; 3:e247-e258.

16. Else LJ, Taylor S, Back DJ, Khoo SH. Pharmacokinetics of antiretroviral drugs in anatomical sanctuary sites: the male and female genital tract. Antivir Ther 2011; 16:1149-1167.

17. Bunupuradah T, Bowonwattanuwong C, Jirajariyavej S, et al. HIV-1 genital shedding in HIVinfected patients randomized to second-line lopinavir/ritonavir monotherapy versus tenofovir/lamivudine/lopinavir/ritonavir. Antivir Ther 2014; 19:579-586.

18. Baeten JM, Overbaugh J. Measuring the infectiousness of persons with HIV-1: opportunities for preventing sexual HIV-1 transmission. Curr HIV Res 2003; 1:69-86.

19. Mujugira A, Coombs RW, Heffron R, et al. Seminal HIV-1 RNA Detection in Heterosexual African Men Initiating Antiretroviral Therapy. $J$ Infect Dis 2016; 214:212-215.

20. Smith DM, Wong JK, Shao $\mathrm{H}$, et al. Long-term persistence of transmitted HIV drug resistance in male genital tract secretions: implications for secondary transmission. $J$ Infect Dis 2007; 196:356360.

21. Graham SM, Chohan V, Ronen K, et al. Genital Shedding of Resistant Human Immunodeficiency Virus-1 Among Women Diagnosed With Treatment Failure by Clinical and Immunologic Monitoring. Open Forum Infect Dis 2016; 3:ofw019. 
Publication: Antiviral Therapy; Type: Short communication DOI: $10.3851 /$ IMP3200

Table 1: Drug-resistance mutations seen in genital secretions and plasma

\begin{tabular}{|c|c|c|c|c|c|c|c|c|c|c|c|}
\hline & & & & HIV RN & copies/ml & NRTI and & NRTI resista & ce mutations & $\mathrm{PIr}$ & sistance muta & ions \\
\hline & & I reatmer & & at v & ek 96 & at $\mathrm{n}$ & k 96 & at week 0 & at $w$ & k 96 & at week 0 \\
\hline & Group & $\begin{array}{l}\text { First-line } \\
\text { regimen }\end{array}$ & $\begin{array}{l}\text { Second- } \\
\text { line } \\
\text { regimen }\end{array}$ & $\begin{array}{c}\text { Cervico- } \\
\text { Vaginal } \\
\text { Samples }\end{array}$ & Plasma & $\begin{array}{l}\text { Cervico- } \\
\text { Vaginal } \\
\text { Samples }\end{array}$ & Plasma & Plasma & $\begin{array}{l}\text { Cervico- } \\
\text { Vaginal } \\
\text { Samples }\end{array}$ & Plasma & Plasma \\
\hline 1 & $\mathrm{bPI} / \mathrm{RAL}$ & $\begin{array}{l}\text { FTC TDF } \\
\text { NVP }\end{array}$ & LPV/r RAL & 242 & $<40$ & $\begin{array}{l}\text { K65R, } \\
\text { Y181C, } \\
\text { M184V, } \\
\text { K219E }\end{array}$ & $\begin{array}{l}\text { Testing not } \\
\text { applicable }\end{array}$ & $\begin{array}{l}\text { K65R, } \\
\text { Y181C, } \\
\text { M184V, } \\
\text { K219E }\end{array}$ & $\begin{array}{l}\text { No } \\
\text { Mutations }\end{array}$ & $\begin{array}{l}\text { Testing not } \\
\text { applicable }\end{array}$ & $\begin{array}{l}\text { No } \\
\text { Mutations }\end{array}$ \\
\hline 2 & bPI/NRTI & $\begin{array}{l}\text { 3TC ZDV } \\
\text { NVP }\end{array}$ & $\begin{array}{l}\text { 3TC TDF } \\
\text { LPV/r }\end{array}$ & 1,330 & $<40$ & $\begin{array}{l}\text { M41L, } \\
\text { A98G, } \\
\text { M184V, } \\
\text { G190A, } \\
\text { L210W, } \\
\text { T215Y }\end{array}$ & $\begin{array}{l}\text { Testing not } \\
\text { applicable }\end{array}$ & $\begin{array}{l}\text { M41L, } \\
\text { M184V, } \\
\text { G190A, } \\
\text { L210W } \\
\text { T215Y }\end{array}$ & $\begin{array}{l}\text { No } \\
\text { Mutations }\end{array}$ & $\begin{array}{l}\text { Testing not } \\
\text { applicable }\end{array}$ & $\begin{array}{l}\text { No } \\
\text { Mutations }\end{array}$ \\
\hline 3 & $\mathrm{bPI} / \mathrm{NRTI}$ & $\begin{array}{l}\text { 3TC ZDV } \\
\text { NVP }\end{array}$ & $\begin{array}{l}\text { 3TC TDF } \\
\text { LPV/r }\end{array}$ & 164 & $<40$ & $\begin{array}{l}\text { D67N, } \\
\text { K70R, } \\
\text { A98G, } \\
\text { M184V, } \\
\text { G190A, } \\
\text { T215Y }\end{array}$ & $\begin{array}{l}\text { Testing not } \\
\text { applicable }\end{array}$ & $\begin{array}{l}\text { D67N, K70E, } \\
\text { K70R, F77L, } \\
\text { F116Y, } \\
\text { Q151M, } \\
\text { M184V, } \\
\text { G190A, } \\
\text { L210W, }\end{array}$ & K20R & $\begin{array}{l}\text { Testing not } \\
\text { applicable }\end{array}$ & $\begin{array}{l}\text { No } \\
\text { Mutations }\end{array}$ \\
\hline 4 & bPI/NRTI & $\begin{array}{l}\text { 3TC ZDV } \\
\text { NVP }\end{array}$ & $\begin{array}{l}\text { DDI ABC } \\
\mathrm{LPV} / \mathrm{r}\end{array}$ & 124 & $<40$ & $\begin{array}{l}\text { M41L, } \\
\text { A98G, } \\
\text { Y181C, } \\
\text { M184V, } \\
\text { L210W, } \\
\text { T215Y, } \\
\text { H221Y }\end{array}$ & $\begin{array}{l}\text { Testing not } \\
\text { applicable }\end{array}$ & $\begin{array}{l}\text { M41L, } \\
\text { Y181C, } \\
\text { M184V, } \\
\text { L210W, } \\
\text { T215Y, } \\
\text { V108L, } \\
\text { H221Y }\end{array}$ & $\begin{array}{l}\text { No } \\
\text { Mutations }\end{array}$ & $\begin{array}{l}\text { Testing not } \\
\text { applicable }\end{array}$ & $\begin{array}{l}\text { No } \\
\text { Mutations }\end{array}$ \\
\hline 5 & bPI mono & $\begin{array}{l}\text { 3TC TDF } \\
\text { NVP }\end{array}$ & $\mathrm{LPV} / \mathrm{r}$ & 907 & 20,748 & $\begin{array}{l}\text { No } \\
\text { Mutations }\end{array}$ & $\begin{array}{l}\text { No } \\
\text { Mutations }\end{array}$ & Not tested & $\begin{array}{l}\text { M46L, } \\
\text { I54V, V82A }\end{array}$ & $\begin{array}{l}\text { No } \\
\text { Mutations }\end{array}$ & Not tested \\
\hline 6 & bPI mono & $\begin{array}{l}\text { 3TC ZDV } \\
\text { NVP }\end{array}$ & $\mathrm{LPV} / \mathrm{r}$ & 60 & 297 & $\begin{array}{l}\text { No } \\
\text { Mutations }\end{array}$ & $\begin{array}{l}\text { Testing not } \\
\text { applicable }\end{array}$ & Not tested & $\begin{array}{l}\text { No } \\
\text { Mutations }\end{array}$ & $\begin{array}{l}\text { Testing not } \\
\text { applicable }\end{array}$ & Not tested \\
\hline
\end{tabular}

Note: FTC=emtricitabine, TDF=tenofovir, NVP=nevirapine, 3TC=lamivudine, ZDV=zidovudine, LPV/r = ritonavir-boosted lopinavir, RAL=raltegravir, DDI=didanosine,

$\mathrm{ABC}=$ abacavir. Resistance testing was performed in all genital secretions samples with a $\mathrm{VL}>40 \mathrm{copies} / \mathrm{ml}$; and in plasma samples with $\mathrm{VL}>400 \mathrm{copies} / \mathrm{ml}$ at baseline (except those randomised to $\mathrm{PI}$ monotherapy) and at week 96. 
Figure 1: Relationship between viral load in plasma and genital secretions

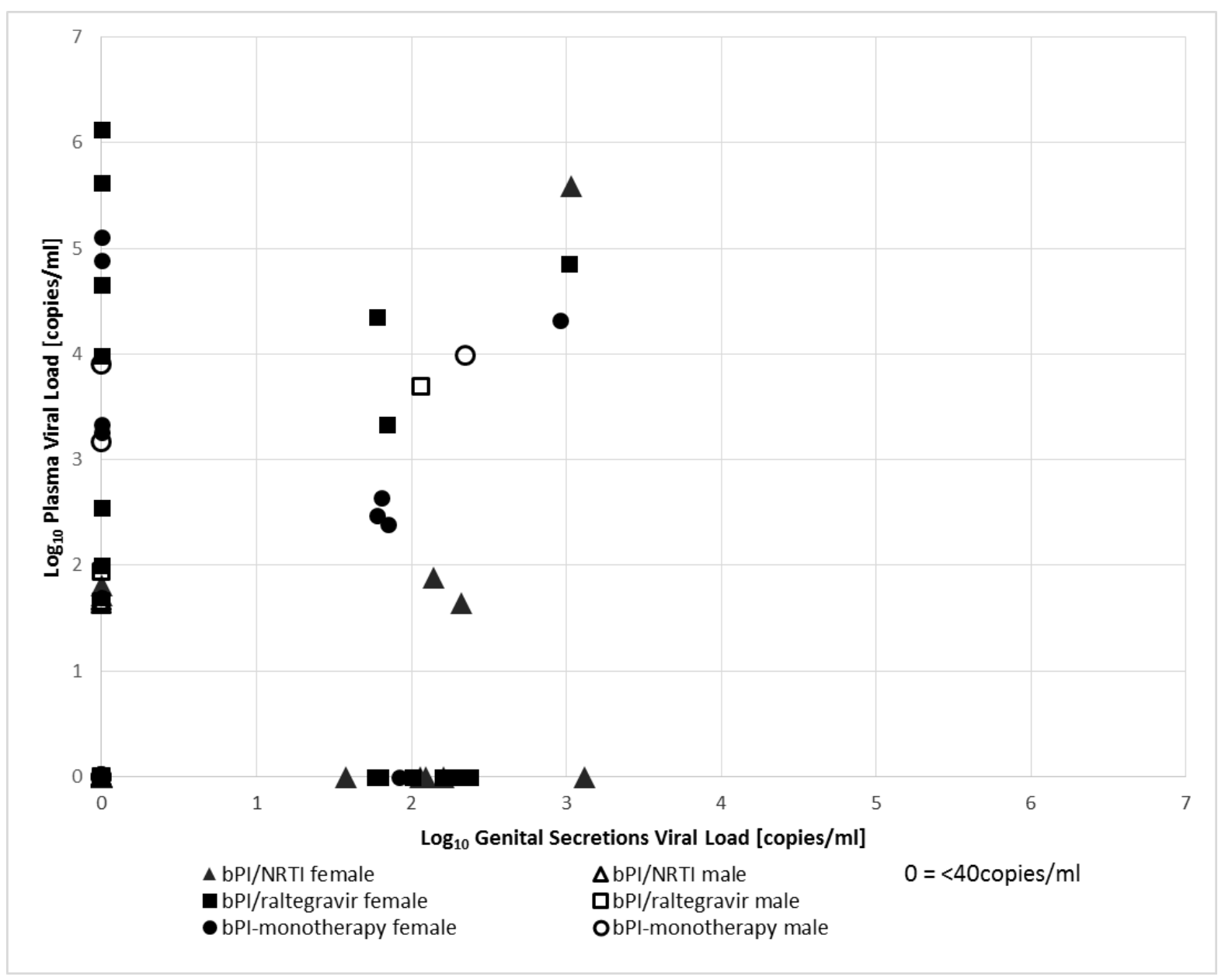




\section{SUPPLEMENTARY MATERIALS}

\section{Members of the EARNEST Trial Team are:}

\section{Participating Sites}

\section{Uganda}

JCRC Kampala (African trial co-ordinating centre; 231) E Agweng, P Awio, G Bakeinyaga, C Isabirye, U Kabuga, S Kasuswa, M Katuramu, C Kityo, F Kiweewa, H Kyomugisha, E Lutalo, P Mugyenyi, D Mulima, H Musana, G Musitwa, V Musiime, M Ndigendawan, H Namata, J Nkalubo, P Ocitti Labejja, P Okello, P Olal, G Pimundu, P Segonga, F Ssali, Z Tamale, D Tumukunde, W Namala, R Byaruhanga, J Kayiwa, J Tukamushaba, S Abunyang, D Eram, O Denis, R Lwalanda, L Mugarura, J Namusanje, I Nankya, E Ndashimye, E Nabulime, D Mulima, O Senfuma

JCRC, Mbarara (97): H Mugerwa, A Lugemwa, E Ninsiima, T Ssenkindu, S Mwebe, L Atwine, H William, C Katemba, S Abunyang, M Acaku, P Ssebutinde, H Kitizo, J Kukundakwe, M Naluguza, K Ssegawa, Namayanja, F Nsibuka, P Tuhirirwe, M Fortunate

JCRC Fort Portal (66): J Acen, J Achidri, A Amone, M. Chamai, J Ditai, M Kemigisa, M Kiconco, C Matama, D Mbanza, F Nambaziira, M Owor Odoi, A Rweyora, G. Tumwebaze

San Raphael of St Francis Hospital, Nsambya (48):H Kalanzi, J Katabaazi, A Kiyingi, M Mbidde, M. Mugenyi, R Mwebaze, P Okong, I Senoga

JCRC Mbale (47): M Abwola, D Baliruno, J Bwomezi, A Kasede, M Mudoola, R Namisi, F Ssennono, S Tuhirwe 
JCRC Kabale (33):H Alima, B Ahimbisibwe, E Atuhaire, F Atukunda, G Bekusike, A Bulegyeya, D. Kahatano, S Kamukama, J Kyoshabire, A Nassali, A Mbonye, T M Naturinda, Ndukukire, A Nshabohurira, H. Ntawiha, A Rogers, M Tibyasa;

JCRC Kakira (31): S. Kiirya, D. Atwongyeire, A. Nankya, C. Draleku, D. Nakiboneka, D. Odoch, L. Lakidi, R. Ruganda, R. Abiriga, M. Mulindwa, F. Balmoi, S. Kafuma, E. Moriku

MRC Clinical Trials Unit: N Paton, J Boles, A Burke, L Castle, S Ghuman, A Hoppe, L Kendall, S Tebbs, M Thomason, J Thompson, S Walker, J Whittle, H Wilkes, N Young, M Spyer

Monitor: F Kyomuhendo

Clinical Expert Review Committee: B Angus, A Arenas-Pinto, A Palfreeman, F Post, D Ishola

\section{European Collaborators:}

J Arribas (Hospital La Paz, Madrid, Spain), R Colebunders (Institute of Tropical Medicine, Antwerp, Belgium), M Floridia (ISS, Italy), M Giuliano (ISS, Italy), P Mallon (University College Dublin, Ireland), P Walsh (University College Dublin, Ireland), M De Rosa (CINECA, Italy), E Rinaldi (CINECA, Italy)

Trial Steering Committee: I Weller (Chair), C Gilks, J Hakim, A Kangewende, S Lakhi, E Luyirika, F Miiro, P Mwamba, P Mugyenyi, S Ojoo, N Paton, S Phiri, J van Oosterhout, A Siika, S Walker, A Wapakabulo,

Data Monitoring Committee: T Peto (Chair), N French, J Matenga

Pharmaceutical companies: G Cloherty, J van Wyk, M Norton, S Lehrman, P Lamba, K Malik, J Rooney, W Snowden, J Villacian 